\title{
The Adaptability Paradox: Constitutional Resilience and Principles of Good Government in Twenty-First-Century America
}

\author{
Stephen Skowronek and Karen Orren
}

\begin{abstract}
Faith in the resilience of the US Constitution prompts many observers to discount evidence of a deepening crisis of governance in our day. A long history of success in navigating tough times and adapting to new circumstances instills confidence that the fundamentals of the system are sound and the institutions self-correcting. The aim of this article is to push assessments of this sort beyond the usual nod to great crises surmounted in the past and to identify institutional adaptation as a developmental problem worthy of study in its own right. To that end, we call attention to dynamics of adjustment that have played out over the long haul. Our historical-structural approach points to the "bounded resilience" of previous adaptations and to dynamics of reordering conditioned on the operation of other governance outside the Constitution's formal written arrangements. We look to the successive overthrow of these other incongruous elements and to the serial incorporation of previously excluded groups to posit increasing stress on constitutional forms and greater reliance on principles for support of new institutional arrangements. Following these developments into the present, we find principles losing traction, now seemingly unable to foster new rules in support of agreeable governing arrangements. Our analysis generates a set of propositions about why the difficulties of our day might be different from those of the past in ways that bear directly on resilience and adaptability going forward.
\end{abstract}

$\Lambda$ merican government boasts such a long history of success in navigating tough times that it is hard to gauge the significance of the problems that currently beset it. Institutions appear dysfunctional, rights feel insecure, rules seem unreliable, parties are polarized,

Stephen Skowronek (1) is the Pelatiah Perit Professor of Political and Social Science at Yale University (stephen. skowronek@yale.edu).

Karen Orren is Distinguished Professor of Political Science at the University of California, Los Angeles (orren@ucla.edu).

Versions of this article were presented at the University of Oregon Law School, Swarthmore College, the Rothermere American Institute in Oxford, and Sciences Po in Paris. We are grateful for comments and criticisms received on those occasions. We also received thoughtful readings from Stuart Chinn, Chris Edelson, Eldon Eisenach, William Forbath, Michael Fotos, Desmond King, Eileen McDonagh, Sidney Milkis, Bruce Miroff, Carol Nackenoff, and the editor and anonymous reviewers of this journal. John Dearborn, Jack Greenberg, and Benjamin Waldman provided able research assistance. norms are crumbling. But what's new about that? Haven't we seen the likes of this before? Haven't we been through a lot worse? The Constitution of the United States has weathered many seemingly intractable difficulties, at least one of which was a truly existential crisis. Adjustments along the way have generated governing arrangements wholly unanticipated by the original design. The nineteenth century saw the rise of a party state, a government recast around political organizations that the framers of the Constitution feared and hoped to avoid. The twentieth century gave us an administrative state, a programmatic government with powers the Constitution's framers could scarcely have imagined. Reformations like these attest to the system's responsiveness and adaptability and to American ingenuity in rethinking relations of power and authority.

For many, this history speaks for itself. It offers assurance that the fundamentals are sound and the Constitution resilient. It instills confidence that the current "crisis of governance" (see, e.g., Dionne, Ornstein, and Mann 2017; Levinson 2012; Reich 2017) is manageable and momentary. Nonetheless, prior experience is an imperfect predictor of future performance, and skeptics are right to resist the easy inference that present difficulties are just more of the same. For starters, it seems plain that historical adjustments have, time and again, altered the 
Constitution itself and that, by dint of past changes, the system of authority on hand to grapple with current problems is different from that which resolved earlier ones. Rather than lull us into complacency, our long history of success might spur us to think more critically about the cumulative effects of these adaptations and how they bear on current prospects. If there is something in that history that should be of special concern for us todaysomething that marks the current impasse as significantly distinctive-it may lie in the dynamics of adjustment themselves.

Adaptation works best when it aims for consistency. Principles of good government are borrowed from the Constitution's formal setup and then redeployed in new arrangements that alter the Constitution's operations. Take the national party convention, a signal innovation of the nineteenth-century party state: it drew on constitutional principles of federalism and representation, but it created new communities of interest that would cooperate across institutions that the Constitution had purposely divided and juxtaposed. The Administrative Procedure Act, a signal innovation of the twentieth-century administrative state, shows something similar. It concentrated in regulatory agencies powers distributed by the Constitution to the Congress and the courts, but it did so by dividing agency rulemaking from agency adjudication according to the constitutional principle of the separation of powers. In both instances, the Constitution provided guidance for innovations that transformed it. Consistency was achieved by elevating its principles over its forms.

The development of American government is full of improvisations like these, each a reasoned institutional response to changes on the ground. Moreover, the record shows that easing formal constraints on the exercise of authority did not just keep the system going; it also opened it up to stakeholders previously excluded from full access to its services and protections. Those hard-won advances on the principle of government by "we the people" are the pride of American political development, and in large measure, processes of adjustment have been assessed from that vantage point. We know a lot about democratization in America, about its initial incongruities, its uneven progress, its major achievements, and its stillpotent adversaries in politics and culture (e.g., Bateman, 2019; King and Smith 2005; Smith 1997). What we know less about is how easing constraints, eliminating incongruities, and facilitating greater inclusiveness have affected the Constitution's capacities to cope with the new issues and demands thrust on it.

Put that way, it may be less jarring to ask whether a government framed in writing some 230 years ago will not eventually encounter some serious problems directly related to its long history of adaptation. The dynamic just described-adaptation at its best-would seem, on its own terms, self-limiting. As constitutional formalities are more steeply discounted, it will likely become harder to find traction in the different principles derived from them. Easing institutional constraints can help in incorporating the interests of a wider range of stakeholders, but it is also likely to make it harder to reach consensus on new rules about how to govern. The intuition to be pursued here is that repeated extrapolations from the same basic forms will push governing principles ever farther from their institutional foundations, rendering them more abstract and less tractable, and that serial accommodations and rearrangements will eventually make it more difficult to say with authority what is consistent and what is not. On this reasoning, opening the old frame up to alternative interpretations of permissible governmental action will not only help the system adjust but will also give rise to a principled free-for-all and hollow the system out.

Call this the adaptability paradox, and tag it a developmental problem worthy of study in its own right. Born of past success and submerged in great democratic achievements, it bears directly on our national faith that the Constitution is self-correcting and that more serviceable arrangements lie just around the corner. As presented, it is just an inference, a historical-structural conjecture, but it is not without contemporary resonance. The previous reset-the administrative state-took hold over the first half of the twentieth century. Politics in our day has become an all-fronts assault on the principles that produced that adaptation, but convergence on an alternative is nowhere in sight. The issues now at the fore did not arrive suddenly with the Trump presidency: American government has been roiling in "transition" since the rights revolution swept the nation in the 1960s and 70 s, and little that has happened in the intervening decades instills confidence that our institutions are slowly edging their way toward the next ingenious resolution. To be sure, there has been no shortage of ideas about what a principled path forward might look like; the prospect now coming into focus is that authority sufficient to sustain support for any one of them has evaporated. That is just what one might expect when the formal arrangement of authority has been hollowed out and all the different principles behind it are thrown up for grabs.

This article addresses the current shakedown of authority with eyes on historical dynamics of institutional adjustment and reordering. Analysis along these lines scouts the contours of a fully formed theory of constitutional development, but the exercise here remains exploratory and largely descriptive. Its aims are to identify basic mechanics of adaptation, to consider their structural implications, and to posit on that basis a plausible diagnosis of problems now widely observed. Drawing on well-known features of the historical record, the analysis looks first to shifts in authority that relaxed the formal structure of this government and increased reliance on its principles. Then, drawing on familiar aspects 
of the current political landscape, it turns to a few core principles and asks how they are bearing up under the burdens of governance now thrust on them. It concludes with a set of propositions about why the difficulties of our day might be different and in ways that bear directly on resilience and adaptability going forward.

Development is not benign. Democratic gains have eliminated the most egregious of the historical incongruities of constitutional government in the United States, giving fuller expression to its principles; in the process, however, American democracy may have outstripped its institutional accommodations and put its future at risk. This sobering possibility breaks into the issues of our day from a position equidistant from others staked out on the left and the right. It is an analytic wedge opening onto an assessment of the current impasse that neither side can comfortably ignore. Conservatives often complain about the loss of system integrity. Their assumptions about greater integrity in times past have, however, always been suspect. The historical-structural account offered here confronts the incongruities of the past directly. In doing so, it discards nostalgia for the way things once were and tackles governance problems as we find them now without insisting that somewhere along the way American political development must have taken a wrong turn (see, e.g., Epstein 2006; Goldberg 2008; Hamburger 2014; Kersh 2016). This approach is equally attuned to progressive concerns for the full range of social problems now pressing for policy solutions. But by pulling historical-structural dynamics into the foreground, it identifies quandaries encountered in the process of democratization and redirects the call to action. When developmental processes compromise the structure of decision-making authority itself, they rob policy solutions of their legitimating anchors and limit the gains to be realized from muscling new policies through.

\section{Structure and History}

A resilient institutional system can be expected to exhibit two properties: (1) at a certain threshold of stress it will maintain itself, balancing commitments and managing conflicts according to relatively stable rules; and (2) beyond that threshold, it will adjust, generating new rules and arrangements that adapt to altered circumstances and restore a semblance of regularity. By these bare-bones criteria, the American system has been remarkably resilient. The Constitution was generously endowed with filters, boundaries, and checkpoints to help stabilize and manage national affairs. For conflicts and crises that were not easily contained, amendments, elastic clauses, electoral swings, and extraordinary lawmaking were on tap. Principles built into the structure-liberal, republican, and democratichave lent meaning to these arrangements and consistency to their serial reordering.
On closer inspection, however, these relationshipsbetween arrangements and principles, and between the adaptability of the structure and its resilience-are anything but straightforward. They are complicated in the first instance by the founding moment itself and the presuppositions of a written constitution. The American framers sought a durable and comprehensive settlement of the outstanding problems of governance. Working with what they thought were timeless principles of institutional organization, they fashioned a government that they expected would manage all contingencies without sacrificing its essential integrity (Gillman 1997; Hamburger 1989). More to the point, they acted on that faith. They took care to secure the Constitution on a separate footing, independent of the institutions that were assigned the everyday work of governing. Their arrangement was ratified all of a piece as the sovereign act of "the people" gathered together in extraordinary conventions, and it became in that way the touchstone of legitimacy for all future action. The procedures for amendment included in the package not only protected against constant revision but also dimmed the prospect that the problems of governance would ever again be considered holistically. Subsequent adaptations have had to work through and around the basic arrangements chosen at that time.

The debates now raging between advocates of "originalism" and advocates of "the living Constitution" attest to the difficulties of maintaining the credibility of this touchstone. The normative high ground of originalism overlooks the essential historicity of the framers' handiwork, whereas the commonsense pragmatism of the living Constitution threatens to unravel it altogether. And that points to a second complication: notwithstanding its conception and ratification as a "new order of the ages," the Constitution was itself an adaptation. That is to say, this reset, like later ones, reorganized operations around shared principles so as to ease the strains mounting on received arrangements. The immediate objective was to bring a bit more of governance under national authority and to relax restraints on its exercise. Notwithstanding the holistic character of the Constitution, the encompassing principles that defended it, or the sovereign act of locking it in, the changes in governance contemplated in its structure were incremental.

In fact, most of governance in America continued on after ratification as it had before- on legal foundations that were far older than the Constitution and more deeply entrenched. Prior rights, untouched by the Constitution's reconfiguration of authority, incongruous with its professed principles, and implicitly excluded from its programmatic ambitions, still did the bulk of the work. Carried over from time out of mind, anchored more in assumption than in argument, and enforced mainly at the local level, these claims regulated and protected much of the previously established order of things. 
These prior rights reached deeper than the formal declarations of the Bill of Rights, which were at the time but additional assertions of the new Constitution's principles. Rights unmentioned and largely indifferent to those principles organized relations throughout early American society: masters over slaves, employers over employees, husbands over wives, parents over children. ${ }^{1}$ With all that authority off the table, the new platform of institutions and principles erected by the Constitution carried a relatively light load. Tacit grounding in governance by other means not only delimited the reach of the framers' arrangements but also helped articulate and bind them. As a practical matter, the new platform drew much of its structural integrity from all the rest of the governing being done underneath it.

When Publius explained how each piece of the new structure would play its part in the whole and would keep the others in their proper place, constitutional forms and principles were aligned just so. In effect, a refined stratum of rights holders was authorized to contend over national matters of concern to them, largely issues of trade and security (Edling 2003). The principled declarations and reasoned divisions that riddled the frame reflected that community's consensus on how best to make decisions within the domain of discretion it set for itself. The new arrangement - the formal structure of federalism, separation, checks, enumerated powers, and mixed representations - served the interests recognized. It assured rights holders anxious about the government's new policymaking capabilities that they could keep everything else the same.

Describing the initial conjunction of history and structure in this way-a constitutional ordering of authority articulated by the concurrent operation of other incongruous orderings - serves both to identify the major fault lines of the system and to bring the mechanics of adaptation more clearly into focus (Orren and Skowronek 2004). As we know, things did not remain the same. The correspondence of principles and formal authority proved shaky from the start, as the former helped expose the incongruous legal relations that supported the latter. One by one, the old social hierarchies were overthrown, and the burdens of governing shifted incrementally upward onto the constitutional platform itself. The implications were twofold: practical operations were pushed farther afield of assumptions embedded in the formal structure of constitutional authority, and principles consistent with that structure were enlisted to accommodate the alternative arrangements improvised. When newly recognized claimants demanded more of government than the original frame had anticipated, when the programmatic interventions necessary to give effect to newfound rights taxed the Constitution's cumbersome divisions, or when the scope of conflict among rights holders widened, principles stepped into the breach. They helped relax formal constraints. They rendered new arrangements compatible with the Constitution. They facilitated the management of a burgeoning array of rights and policies.

These dynamics are equally instructive when considered the other way around. Because all these adjustments were incremental, the burden on principles increased gradually. Governance beyond their reach remained substantial even as the community of rights holders expanded, and those remaining boundaries helped ease the way for those incorporated to reach some new accommodation on how to govern. In this way, tacit grounding in governance by other means aided the whole long history of adaptation. As in the initial reset of 1789, the new issues of governance accommodated in subsequent rounds of reordering were limited, and stakeholders could buy into new arrangements on the assurance that other governing relationships of concern to them would remain unaffected. Note also, however, that regenerating rules and rearticulating arrangements on these terms have an implicit time horizon. Sooner or later, the last boundaries will be removed, everyone will be included, and governing arrangements, once circumscribed, will encompass all societal relations. The outstanding issue in the adaptation of this government - the historical-structural question-is this: What happens when it's principles all the way down?

\section{Adaptations and Bounded Resilience}

A fully formed theory of constitutional development would explain the sequential overthrow of the old hierarchies. Here that history is taken as given, the rudimentary facts well known. This is not to dismiss the many complications, to assume some teleological inevitability, or to diminish the significance of any yet unfinished business, but instead to zero in on postconstitutional processes of adjustment and on the bounded resilience of the various arrangements arrived at.

Consider first the party state of the nineteenth century. The early decades of the nineteenth century witnessed a revolt against rule by notables, the extension of voting rights to white men, and rapid expansion westward (Wiebe 1995). All of this opened the national government to a wider range of claimants. It also sharpened the national expression of political conflict and abraded more deeply seated rights. In response, a new breed of state managers grasped an alternative organizing instrument, political parties.

Although previously seen as a threat to the integrity of the Constitution (Hofstadter 1969), political parties endorsed a fuller expression of the principle of popular sovereignty, and by ratifying changes on the ground, they accommodated a significant broadening of participation in political affairs. Simultaneously, they reorganized constitutional relationships from bottom to top. Parties integrated national power into local centers of political activity, they coordinated action across the separated 
branches of the national government, and they facilitated distribution of the federal largesse across a sprawling territory.

Parties also served as a containment mechanism. Their bottom-up organization protected local discretion over the new conflicts that were brewing. Antebellum party managers built rival, cross-sectional coalitions that braced the nation-state against the rising slavery controversy and assured anxious slave masters that the new democracy would protect their other interests (Silbey 1983, 1985). The national "party system" directed political conflict back to policy issues closer to those the Constitution had been designed to address: tariffs, banking, infrastructure, and westward expansion. This was bounded resilience. When the conflict over slavery finally overwhelmed the institutional arrangements designed to contain it, the system collapsed in constitutional crisis and civil war.

The next attempt at adaptation proved a misfire. In the war's aftermath, amendments ratified to aid in the reconstruction of government gave rights to former slaves and authorized Congress to create new arrangements for the accommodation of that momentous extension of constitutional principles. But despite the seemingly authoritative rearticulation of principles, the old forms did not give way to durable inclusions. This "failure" of "Reconstruction" offers a stark illustration of the tradeoffs involved in all such efforts. The residual claims of federalism, the separation of powers, and the decentralized parties themselves proved formidable obstacles to the extension of programmatic supports for the freedmen. Reform energies exhausted themselves without providing protections adequate to the incorporation of the new entrants. Courts limited the infringement on the rights of others and minimized the structural disruptions (Orren and Skowronek 2004, 133-43). With the incursion on boundaries contained, the party state resumed, with only minor adjustments, organizing national affairs and protecting local prerogatives. In effect, an elaboration of principles was stymied by the resilience of old forms. One way or another, adaptation is always testing that relationship.

More decisive breakthroughs came in the twentieth century. The rise of an administrative state in its early decades tracked deepening industrial conflict and culminated during the New Deal with the displacement of the ancient common-law ordering of workplace relations and a ratification of workers' rights to organize and bargain collectively with their employers (Orren 1992). With the interests of the working class incorporated into a contentious "industrial democracy," the bottom fell out of the Constitution's Commerce Clause. In effect, all the nation's commerce became subject to federal regulation, and the formalities of "dual" sovereignty gave way to a "marble cake" arrangement, in which relations between the state and national governments grew more pervasively "cooperative" (Corwin 1950; Strong 1938). As programmatic regulation of the national economy expanded its reach, much of the responsibility for management shifted off the formal structure of the Constitution and onto bureaus of experts. Constitutional relationships were reengineered in the wake of the New Deal around accommodations to nonpartisan administration and agency rulemaking. Interrelated statutes enacted in the years straddling World War II-the executive Reorganization Act of 1939, the Administrative Procedure Act of 1946, the Legislative Reorganization Act of 1946, the Employment Act of 1946-hammered out the new settlement.

Several features of the system that congealed in 1946 stand out. First, whereas the Reconstruction amendments had put the burden of following through squarely on the national legislature, the system of 1946 was broadly based and more fully articulated (Michaels 2017, 39-78). The new order enlisted support and solicited supervision across the board: from the president, the Supreme Court, and the Congress. Equally noteworthy, the reordering rested entirely on statutes. An institutional rearrangement as comprehensive as this would have been hard to achieve through the formal amendment process. By the same token, however, the reset relaxed core distinctions drawn in constitutional law. Lines demarcating structure from policy, and rights from policy, grew more porous, and the domain open to alternative interpretation and political choice widened correspondingly (Orren and Skowronek 2017).

Not surprisingly, reestablishing order under these circumstances compounded the burden on principles. Government reached farther afield of formalities to rationalize these arrangements, relying, for example, on science and expertise to gain the necessary cooperation among the authorities separated by constitutional design. Faith in administrative objectivity and professional competence informed the supervisory duties of each of the branches and compensated for the relaxation of formal divisions. Finally, and with all due regard for the heavy lifting done by these principles, prior right still left much out of bounds. As was the party state of the nineteenth century and the original Constitution before that, this reset too was held together by what was left out. The South, keen to tap into the new services on offer, bought into the new arrangement on assurances that racial hierarchies would remain undisturbed. Representatives from the region insisted on statutory stipulations that denied African Americans access to many of the new order's benefits. As Ira Katznelson and his collaborators have detailed, Southerners "inserted provisions into the Wagner Act, the Social Security Act, and the Fair Labor Standards Act that excluded farm workers and domestic service workers, the categories of work for most Southern blacks in the labor market" (Bateman, Katznelson, and 
Lapinski 2018, 397; see also Katznelson, Greider, and Kryder 1993). In effect, the Southern delegations in Congress became the political balance wheel of America's industrial democracy. Richard Hofstadter $(1949,150)$ put it this way: "no legislation could be passed, on either economic affairs or race relations, which they would not accept." The new arrangements remained resilient so long as the rights of racial minorities were kept beyond reach.

The bounded resilience of America's administrative state- the principled consensus, practical cooperation, and rule-based regularity attained in the post-New Deal settlement-rested on limits that the rights revolution shattered. The civil rights movement broke the back of the remaining structural protections for social hierarchy, and for a critical period, cooperative partnerships between the state and national governments gave way to "coercive federalism," with the national government dictating the terms of inclusion to the governments below (Kincaid 1990). Since that breakthrough, the incorporation of new claimants has picked up steam to include other racial minorities, women, young people, and gay people (Skrentny 2004). So if there is something categorically new about the problems that beset American government today, it is just this: for the first time, there are no exclusions from the Constitution's principles, no elements of society dealt with through localism and prior right still available as bargaining chips for new deals. ${ }^{2}$ National institutions stand fully exposed on a field of choice where principles range free against the historically weakened boundaries of the formal structure. Every issue is a national issue; all authority is jumbled; discretion is broad and politics unbridled.

These are the cumulative effects of development, and they would seem to weigh against another institutional reset. The shedding of old incongruities is surely the Constitution's crowning achievement, but the free play of its principles has not made it easier to forge agreement on a consistent path forward. On the contrary, constitutional government in the United States faces a new and severe test. When there are no issues to bracket and exclude, it is harder for these old forms to hammer out new accommodations among interests, harder for them to sustain rules, harder for them to firm up commitments and priorities, and harder for them to contain principled conflicts within the burgeoning community of rights holders. When the scope of political choice in social relations is wide open, interpretations of the proper ordering of authority find no firm resting place, no durable settlement. When it's principles all the way down, no one can discount the importance of who is next in charge. Mutual forbearance is eclipsed by mobilization and countermobilization, each wave intent on rearranging authority for itself. The long history of bounded resilience is over, and for all appearances, governance is at wit's end.

\section{Principles Losing Traction}

There was never a time when American government was not under some sort of stress. It has persevered through principled adjustments, institutional accommodations, and a lot of sheer indifference to incongruity. A schematic rendering of this history points as well to a profound change in system mechanics. Responses to heightened levels of stress have relaxed constraints, eroding by degrees the system's exclusions, filters, and boundaries. In other words, adaptations that have reduced vulnerabilities in the near term have also undermined the properties on which the Constitution relied historically for selfmaintenance, interest management, and the restoration of regularity. Never before has a modus vivendi within this government been so completely dependent on principles, nor has the constituency for a principled consensus ever appeared so weak.

A description of the mechanics of adaptation cannot by itself establish the limits of institutional accommodation. That too awaits a fully formed theory, one that relates social change to institutional capacity more directly. But this description does draw attention to a little noticed consilience of results from multifarious sources and across a wide range of disparate developments (cf. Burnham 1993). It is hardly surprising that the social revolution of the 1960s and 70s unsettled institutional relationships across the board. What is notable, however, is that the broad reworking of principles that began at that inflection point has failed over the past half-century to regenerate rule regularity or reorder institutional relationships. On the contrary, the pattern observed is of principles losing traction, seemingly unable to sustain authority for any agreeable rearrangement. To the extent that we find principles consistent with the Constitution failing over a long period of time to sort things out and generate support for new rules of governmental action, the case builds for closer attention to the adaptability paradox. To the extent that we observe a shakedown of institutional authority accelerating along a number of different dimensions, with principles fueling the very conflicts they are meant to mollify, the diagnosis offered here becomes more plausible. Evidence of this is pervasive. The adaptability paradox hovers over principles old and new, informing qualitative shifts in government and politics.

\section{The Rule of Law}

The leading principle of good government, the rule of law, relies first and foremost on faith in the independence and impartiality of judges. Judicial confirmation hearings still elicit ritual endorsements of these values: "I have no agenda," said nominee John Roberts. "My job is to call balls and strikes and not to pitch or bat" (Roberts 2005). Or as Brett Kavanaugh (2018) insisted more recently at his own, more explosive confirmation hearing: "The Supreme 
Court must never be viewed as a partisan institution.” Neutrality is always a testy proposition in a democracy. Skepticism about these pretensions dates back to the Jeffersonian critique of a Federalist lock on the judiciary, and court battles have been a prominent feature of the politics of adjustment ever since. Until recently, however, the fallback position - that justice will eventually conform to a new political consensus - has helped to restore faith in the rule of law and to keep those politically inspired court battles intermittent (Dahl 1957). That fallback is now in jeopardy. As full inclusion has weakened consensus, it has also exposed the Supreme Court's authority as safeguard of the rule of law. The problem is twofold: deepening political divisions make government action more reliant on faith in neutral arbiters, while at the same time they rob the principle of neutrality of much of its political purchase.

The rights revolution both expanded judicial discretion in reconciling competing principles and narrowed the ground of national political agreement. Ever since, the judiciary has been under intense political pressure, its traditional claims to authority swept up in an escalating battle for control over the shape of social relations. One effect has been to subject judicial appointments, top to bottom, to ideological litmus tests. Begun by Richard Nixon and institutionalized by Ronald Reagan, intensive political screening by rotating bands of partisans has extended the contentiousness and irresolution of the political branches into the courts (Engel 2011). When high-profile Court decisions divide sharply according to the partisan affiliation of the appointing president, faith in the rule of law corrodes, as does the independent authority of the Court itself.

A related effect is the practical conflation of judicial reasoning about the scope of rights and of the boundaries of structure with policy choices. Consider federalism. In its 1976 decision, National League of Cities v. Usery, the Court began what would become a long, halting campaign to push back against the incursions of the New Deal and the Great Society and to restore a principled integrity to the federal structure of American government. Less than a decade into that effort, the swing justice on the Usery ruling bolted, and a new majority declared that efforts to protect the states' "traditional government functions" from national regulation were "unworkable," bereft of any "organizing principle," and an affront to "democratic self-governance" from an "unelected judiciary [that] make[s] decisions about which policies it favors and which it dislikes." Tilting toward democratic principles, the new majority in Garcia v. San Antonio Metro. Transit Authority $(1985,531-47)$ turned the boundaries of federalism into a matter for the political process to decide. Decisions like these underscore just how difficult it has become to determine with authority what is consistent and what is not. Twenty-eight years later, another principled defense of the federal structure, this one against the alleged ravages of the Voting Rights Act, shows markings of a similar foray. Shelby County v. Holder (2013) also broke 5-4. The dissenters presented compelling arguments that the majority had the value of rights and structure exactly backward, and political efforts to fashion a workaround became an opposition priority (Houk 2015). In fact, by recognizing Congress's authority to act and objecting only to the way it had gone about its rightful business, the majority in Shelby provoked more than it resolved. It put little light between the rule of law and the judges' preferences and appeared, despite itself, to solicit political responses. As those distinctions get harder to draw-as the practical entanglements of structure, rights, and policy become harder to sort out convincingly - settlements become more tenuous.

Finding an authoritative voice for the law is more difficult now, not because the judges lack principles, but because principles are all there are to work with in setting the rules to which others are expected to defer. The settled boundaries (of federalism, for example), which once stiffened the rules with firm backstops on interpretation and choice, have gone the way of social exclusions. It not just that there are always competing principles that point some other way; it is that there is no longer anything beyond the play of principles to delimit the choices made. Individual judges seeking consistency in action do have recourse to "theories" of constitutional interpretation, but there are now an unprecedented variety of those. Each builds on a different set of constitutional principles, and adherence to one or another serves as a proxy for support of a contentious set of policy choices.

Chief Justice Roberts has been alert to the dangers. He has identified bloc-like voting on major cases and the appearance of stark ideological divisions on the Court as the most serious threats facing judicial authority today (Barnes 2008; Caplan 2015; Rosen 2007). But there is no sign that anyone is interested in providing relief. Since Roberts first expressed these concerns, Senate majority leaders Harry Reid and Mitch McConnell have abandoned supermajority requirements for court appointments, easing the way toward an even more ideologically charged, policy-driven judiciary. In 2016, the Senate refused to consider President Obama's nomination of Merrick Garland to the Supreme Court, and after alerting the nation to the potential alteration of the ideological balance on the bench, its leadership actively encouraged political mobilization around the vacancy. Donald Trump, the Republican presidential nominee, followed up, rallying support for his candidacy by brandishing a list of prospective judicial appointees certified by conservative political action groups. As president, Trump has called into question the motivation behind adverse judicial rulings, cast aspersions on the integrity of the judicial process, and promoted his own appointments to the court as a political service delivered as 
promised to his electoral base (Blake 2017; Gstalter 2018; Nelson 2018). Pressures now are mounting on the "blue slip" hold enjoyed by senators from a nominee's home state (Carney 2017).

This accelerating erosion of institutional protections for the principle of the rule of law- its de facto fusion with national party combat, electoral mobilization, and policy demand-is a burden the Court is unlikely to shake. The justices can insist against all evidence that their work is unaffected, that there are no "Obama judges" or "Bush judges." They can choose to take up fewer cases for review, they can allow greater interpretive leeway in the various appellate jurisdictions below, and they can strategize to confound partisan expectations with an occasional "swing" vote, but all that is more or less desperate coping with developments that have compromised the Court's central mission to say with authority what the law is (Liptak 2018). As perceptions of the Court's neutrality erode, we can expect challenges to that authority to become more routine.

\section{Competence}

In its rise to prominence, the administrative state promised to surmount the limitations of courts and parties (Skowronek 1982). Institutional reformers in industrial America responded to demands for enhanced managerial capacities with new principles, elaborated over many decades, that transformed constitutional relationships. Policy science, grounded in objective analysis, technical expertise, and professional judgment, provided a "substitute" for older forms of authority: it promised to ease checks, promote cooperation, and provide a new "discipline" for democracy (Lippmann 1914, 150-51). As with judicial neutrality, acceptance of neutral competence in administration was contingent and never taken at face value. Perceptions of political bias at the National Labor Relations Board, for example, drove enactment of the Administrative Procedure Act (McNollgast 1999; Shepherd 1996). But the general reworking of constitutional relationships that culminated in 1946 provided a new framework of accountability, one that accepted administrative competence as a vital principle of good government. $^{3}$

Then, with the opening to new rights and a correspondingly wider range of programmatic interventions, the power of administrators was more fully exposed, and the centerpiece of the received order became more contentious. In the 1970s, each of the three branches began to reassert its constitutional prerogatives more aggressively, with the effect of slowly pulling administrative management into a principled melee. This resurgence of formal reasoning, after decades of adjustment to its practical limitations, has done less to eliminate dependence on administration than to cast doubt on administrative competence and compromise administrative rationality. With everyone doubling down on principles, the value of regularity is getting buried in divergent purposes and shifting political winds. The administrative state-a formation that prioritized rules, professional authority, and cooperation around expertise-is a thing of the past.

To subordinate administration more directly to the White House, presidents drew on the constitutional principle of a "unitary executive" (Calabresi and Yoo 2008). The pattern since the Nixon administration has been to sideline instruments of interbranch coordination lodged by Congress in the Executive Office, to concentrate agenda control in the political offices of the West Wing, to extend the reach of loyal operatives deeper into the administrative hierarchy, to bypass Senate confirmation through the designation of policy czars and the use of interim appointments, and to set policy unilaterally through executive orders (Hult and Walcott 2004; Kinane 2018; Mayer 2001; Moe 1985; Nathan 1983; Sollenberger and Rozell 2012). Congress resisted this drive toward presidentialism (Sundquist 1981), but by reasserting its own constitutional authority as the premier lawmaking body, it too closed in on administrators. Among other things, it established the Congressional Budget Office to compete for agenda control, it recast its General Accounting Office as a General Accountability Office for tighter program supervision, it wrote more detailed statutes, and its Congressional Review Act made it easier for legislators to reverse agency rules. The Court too expanded its stockpile of supervisory rules, allowing it to tighten or loosen its review of agency decisions more freely case by case. Each rule is grounded in a principle consistent with the Constitution, but it has proven difficult to find rhyme or reason in the application of one or another (Eskridge and Baer 2008). In recent action, for example, the Court has signaled a readiness to discard its fabled Chevron doctrine, a "settlement" from the 1980s that promised to recognize congressional, presidential, and administrative prerogatives and to limit judicial review accordingly. Such deference, the Court now asserts, need not apply to "major questions" (Emerson 2017).

This irregular, all-fronts squeeze on administrative competence presents itself as a revival of formal, constitutional principles of accountability. But the Constitution did not anticipate the administrative state, and its adaptation to that new arrangement rested on the semblance of a consensus on new ordering principles. By itself, a revival of formalism is unlikely to reorder things again, if only because the formal principles of control offer no coherent response to the altered conditions of government that gave rise to the administrative state in the first place. What the reversion to formalism really reflects are widening disagreements about the programs administered and the sustained absence of any new consensus on how to proceed. In these 
circumstances, constitutionalism degenerates into a kind of "lawfare," where raw, policy-driven calculations subordinate rules to the unbridled instrumentalism of the moment. ${ }^{4}$

As faith in administrative competence has eroded, public administration has found itself drawn ever more directly into the crosshairs. Efforts to circumvent the civil service with governing arrangements allegedly more in keeping with the nation's core principles also trace their origins to the 1970s. Mounting a critique of bureaucratic inefficiency, of agency "capture" by private interests, and of the general incompetence of "big government," the "law and economics" movement promoted privatization, marketization, and contracting out. These alternative formulas have not generated enough traction to displace public administration altogether, but they have produced a competing system that operates indiscriminately all around it. The greater efficiency of privatization is hotly disputed, but what has become increasingly clear is that it empowers politically appointed agency heads to pursue policy goals free of regulations that constrain regular government employees, regulations that were designed to keep the rest of civil society apprised of their actions. As Jon Michaels (2017, 119-41) has recently detailed, privatization is not the more principled solution; it is merely another "constitutionally fraught" solution boasting some principles of its own.

More recently, political skepticism about the principles that built the administrative state pushed beyond the high-minded concerns circulating through the nation's think tanks and accelerated into a full-blown populist revolt. President Trump took skepticism of agency cultures to a new level of hostility. Efforts to staff the executive branch slowed to a crawl, and finding managers of sufficient political loyalty became more difficult (Cook and Restuccia 2017; Kinane 2018; Nelson 2018). At the same time, Congress sidelined its own budget office, dismissing forecasts by its chosen experts when they failed to accord with the programmatic priorities of the majority (Rappeport 2017). On the other side are the constituencies for programs under assault. They rallied a countermovement around the slogan "I-believe-in-science" (Clinton 2016; Concerned Members 2018; Sasse and Tran 2017), and they cheered career administrators as they pushed back on behalf of knowledge-based governance by competent professionals (Restuccia, Levine, and Toosi 2017).

This battle of principles has upped the ante. Public pushback on behalf of career administrators undermines faith in the actions taken by elected politicians, and it raises awkward questions about whether formal authority is an adequate basis for the government's choices. It also feeds already aroused suspicions of administrative power and of political biases embedded within public administration itself. Skeptical partisans in the White House and
Congress now routinely identify administrators and their support networks with a "deep state" that defies constitutional authority and democratic will. That has the makings of a principled free-for-all, one with the potential to tear the government apart, and a detached observer is hardpressed to tell which side is mounting the coup.

\section{Transparency}

As once-reliable principles have lost their purchase, government has reached for others. Privatization was one of those new lifelines. Transparency, a principle quite at odds with privatization, is another. It too projects consistency with the system's fundamental values. Record keeping, access, publicity, candid communication: all are staples of accountability in democratic governments.

In the 1940s and 50s, when interest competition was broadening and more governing was being done directly in interactions between administrative agencies and private groups, the vital center was still expressing confidence in the old safeguards. "Pluralists" assured the nation that the "rules of the game" could regulate the informal and far-flung exchanges of the administrative state, keeping the system open, responsible, and balanced (Truman 1951). Then something changed. The polity grew skeptical of the rules of the game and ratcheted up its demands for accountability. The new principle of transparency cast government as a black box; it expressed mounting suspicion of its internal workings and dismissed its self-regulating pretensions. For several decades now, the Constitution has been operating in a political environment of pervasive mistrust of its basic institutions.

The "right to know" first disturbed pluralist pretensions during the Cold War by taking aim at an alleged "militaryindustrial complex" (Schudson 2015). Demands to tear down the "paper curtain" of secrecy surrounding national security policy were an early indicator of just how difficult it would be to run a more active government on the principle of transparency. Nonetheless, the "right to know" what the government is doing broadened and stiffened its claims in the 1970s, just as political agreement on what it should be doing dissipated. This time government responded. It met its ballooning credibility problems with open meeting laws, freedom of information laws, watchdog protection laws, and data disclosure laws (Arnold 2014). But this effusive endorsement of a new "culture of transparency" has proven an awkward expedient. The promise of full disclosure was an accommodation to the reality of full exposure to interests in conflict, and with each interest demanding that government act decisively on its behalf, the new standard could not but run afoul of new pressures to deliver the goods.

The burden of sorting this out now falls on a variety of competing principles, and that again points to the limitations of principles alone in resolving the problems addressed. A maze of conditions, exceptions, classifications, 
and constitutional prerogatives circumscribes transparency. Many of these restrictions protect the rights of individuals and the structure of the government, but their effect is to make it harder to discern consistency in the application of any principle. Calls to let transparency "reign supreme" stigmatize limits and grate against the fine distinctions that government reserves for itself (Dinan 2018).

Initially, when demands for transparency first signaled doubts about the inner workings of the administrative state, there was hope that an administrative solution might be found. The government trained a cadre of "access professionals" to manage its increasingly testy interactions with journalists and stakeholder interests according to set rules. But the "right to know" has long since become an unruly catchall, pushing relentlessly against the boundaries bidding to contain it. It now holds government in the grip of sensational revelations, siege-like investigations, and leak wars. It has become a political weapon deployed to undermine the credibility of opponents, the authority of institutions, and any actions that they take. When Donald Trump refused to release his tax returns or to provide access to the visitor logs of the White House, he fueled suspicions of collusion and plutocracy (Donegan 2017). His stand on behalf of individual privacy and institutional privilege was indeed a conspicuous departure from the recent practice of presidential candidates. Arguably, the case was otherwise when opponents demanded that Barack Obama prove his eligibility for the presidency by producing his birth certificate and that he release his college transcripts so that people could determine whether affirmative action explained his success (Abcarian 2012; Reeve 2011). The right to know, however, is intolerant of fine distinctions. Its advocates appeal to a court of public opinion, where suspicions run deep and where "the principle of the thing" is in the eye of the beholder.

A spectacle at the top, this shakedown of authority is far more worrisome lower down the government hierarchy. Administrators and advisors routinely feed information to journalists in hopes of heading off the initiatives of their superiors, and rogue disclosures of classified material blur the distinction between patriotism and treason (Goldfarb 2015). Corporate interests use the principle of transparency against the government's protections for privacy. In their hands, the right to know leverages challenges to regulations based on research that shields information about individuals, including much of government research related to disease and environmental hazard (Friedman 2018; McGarity and Wagner 2008). In recent action, the right to know has, once again, charged headlong against the most basic privileges the state holds out for itself. In 2018, a Republican majority on the House Intelligence Committee seized on the cause of transparency to attack its erstwhile charge, the intelligence agencies. Without a hint of irony, their Democratic opponents rushed to a defense of the "secret" FISA court, decried disclosure as a threat to national security, and accused the committee majority of using "selective declassification" to undermine a Justice Department investigation of its fellow partisan in the White House.

Offered as a lifeline for good government in our time, the principle of transparency is itself flailing. Unable to resolve the legitimation problems it was intended to address, it has become another cudgel in the political brawl. Repeatedly swept up in a wonderland of distortion, it has turned into an accessory to the general shakedown of institutional authority.

\section{E pluribus unum}

An old saw has it that America is a set of ideas, a nation held together by the universal principles it espouses. The American Constitution upholds equal rights, equal protection, representation, toleration, and individualism. Blind to difference and open to all, these principles lend support to a nation of great diversity. Repeatedly, reformers have leveraged these ideals against local prejudice, social hierarchy, and rule by prior right. Those efforts have, in turn, expanded the powers of the federal government, broadened the base of rights holders, and created a more diverse polity in fact. Nations, however, are historical formations, and the baggage of time and place weighs heavily on the elaboration of universal principles. Now that reality has caught up with principles, diversity-in-fact is testing the relationship between liberalism and nationalism, and government finds itself beset by an accelerating culture war.

The accommodation of diversity in nationality, $e$ pluribus unum, is an ideal that predated the Constitution and, in no small measure, justified it. But as the long history of exclusions suggests, early connections were closely circumscribed. Diversity made a relatively tame appearance as a constitutional principle in Publius's arguments for an "extended republic." The emphasis there was on the greater variety of property interests to be represented in the national legislature and on the security provided thereby for represented minorities against the formation of tyrannical majorities (Madison 1788). As a principle of good government and a rationale for federal empowerment, diversity promised to moderate the ambitions of each interest represented at the center and to help policy decisions attain a semblance of a national consensus.

This argument for mutual protection through diverse representation was undercut by the rise of the party state, which facilitated the national formation of programmatic majorities, and even more so by the Civil War, which raised the specter of a partisan majority in the North empowered to force the incorporation of new rights holders in the South. Ironically, it was the defeated secessionists, suddenly vulnerable in their own locale and 
desperate to moderate the new powers of the postwar republic, who revived the principle of unity in diversity. They made it, once again, a condition for the exercise of federal authority, the very premise of the South's reentry into the national government. This time, however, they gave the idea a cultural spin, all the more ominous for its sheer perversity. The true cause of reunion, it was said, was the renunciation of all "sectional" programs and a guarantee of mutual respect for the "different ways of life" found within each section (Hill 1876; Skowronek 2006).

When the rights revolution finally shattered that pretension and opened things up, it forced a reckoning with tensions long simmering within the idea of a diverse nation bound together by universal principles. No sooner did a more muscular national government throw its weight behind "affirmative action" for new rights holders than others pushed back in defense of equal treatment. Justice Lewis Powell, a son of the Old South, hit on a compromise (Walker 2010). His opinion in Regents of the University of California v. Bakke (1978) recast diversity. No longer would it be a vital protection for rights holders or a condition for national empowerment; in Powell's hands, diversity became just another goal. Hanging on as a legitimate public purpose, the principle could be promoted through policy, but only if its advocates could show that their methods minimized any infringement on other people's rights.

The Bakke decision strained for consistency without producing much traction. Instead, it drew out the historical mismatch between liberal principles and national realities. Far from sorting through the dissonance, it has pulled the country deeper into a cultural quagmire. On one side, the reality of greater diversity bears down on assertions of national authority with the full weight of past injustices. Recognition is no simple matter for new rights holders, because the cumulative consequences of local repression and a glaring record of categorical exclusion lend a hollow ring to belated offers of incorporation into the national community. "Multiculturalism" resists mere accommodation, "identity politics" conditions the legitimacy of national action, and old forms no longer instill confidence in "mutual protection." More troubling still is the reaction of those who experience the new inclusiveness as an infringement on liberties previously enjoyed. Animated by their own brand of identity politics, they eye proponents of diversity as a threat to the nation's historic character, and they eschew cosmopolitan demands for rights, recognition, and representation in defense of a more full-throated Americanism.

Donald Trump did not begin the culture wars. He has, however, effectively dispelled any illusion that cultural divisions are just a historical hangover and that John Dewey's "great community" (1927, 143-84) lies just around the corner. It is less certain than ever that liberal principles inevitably win out.

\section{Balance}

The framers' new science of politics aimed for balance: that was the principle that held all their other principles together. The framers lodged balance in structure, in the composition and arrangement of institutions. The House of Representatives balanced majority with minority interests; the Senate balanced nationalism with federalism; the Electoral College balanced large states with small states; checks balanced powers; and the whole panoply of divisions and separations balanced interests in policy against protections for rights. Because the equities were engrained in the arrangements themselves, the assumption was that no one would have to work very hard to discover them. By and large, they would be upheld impersonally, operationally, automatically. To be sure, judges were tasked to keep watch over these arrangements, but so long as they protected their integrity, the equities could be expected to take care of themselves.

Under the pressures of development, however, formalities repeatedly fell short. At times, as in the Missouri Crisis of 1820, the principle of balance could be upheld by simple extension. An informal "balance rule" was invoked to maintain an equilibrium of free and slave states over the course of westward expansion (Weingast 1998). But at other times, one set of principles steamrolled other concerns, upsetting the balance and opening the structure to a major transformation. That was the case with the Reconstruction amendments. When the principle of balance is reasserted after a shake-up like that, the institutional arrangements on which it is supposed to rest become less self-evident and the equities asserted more contestable. The doctrine of "separate but equal" (Plessy v. Ferguson 1896) was a bold declaration of principles purporting to settle the new conflicts among rights holders that had rumbled out of Reconstruction, but as a practical matter, the balance struck in that rule was glaringly onesided.

All these adaptations claimed consistency with the Constitution, but by degrees, the formal structure of government was doing less of the work of producing a balance, and the pressure to maintain some semblance of equity was falling increasingly on the officeholders themselves. Recognizing these pressures, progressive reformers in the early twentieth century sought to shift responsibility for finding the right balance from structure per se and onto "representative men exercising discretionary authority” (Croly 1914, 41). This so-called revolt against formalism charged political leaders to produce equities proactively, through "constructive discriminations" (Croly 1909, 193-206; White 1947). The legal pragmatism of Oliver Wendell Holmes, moving away from categorical rights and tying rights instead to the "neighborhood of principles" in which they operate, did something similar for judges (Hudson County Water Co. v. 
McCarter 1908). This intellectual shift in the search for balance-from the reliance on structure and rights to a reliance on policies and principles - presaged the political free-for-all that would follow on the decisive social breakthroughs to come.

The institutional foundations of balance were strained to the breaking point when the Court set aside the last of the structural restraints on minority rights in favor of "all deliberate speed" in realizing equal treatment and when Congress followed through with civil rights legislation. Since then, the constitutional principle of balance has come to turn on a proliferating set of judge-made rules determining the degrees of "scrutiny" through which the scope of rights and the appropriate range of policy can be divined. Categories have blurred, judgment calls have become pervasive, and judging itself has become harder to distinguish from legislating. Observers of all stripes worry about constitutional law in this age of judge-made balance, fearing that it "has lost its ability to persuade" (Aleinikoff 1987, 983; Urbina 2017).

The problem of "legibility" that plagues today's balancing rules brings full circle this survey of the burdens mounting on principles. This is, after all, the same development that has magnified the sway of political considerations in judicial selection and threatened faith in judicial impartiality. Officers throughout the government are now charged to strike the right balance by their own lights. Indeed, balance is no longer an institutional principle at all. If there is a shared standard that justifies action on this score, a precept that all officers espouse in finding the right balance, it is the economic principle that benefits should outweigh costs. Any hope of reordering government on that ground seems slim, because costs and benefits are the very stuff of political contestation. The President's Office of Information and Regulatory Affairs applies cost-benefit analysis to agency rulemaking, but the standards it uses in that calculation change with the preferences of each new incumbent who comes along (Croley 2003; Waddell 2018). Chief Justice Roberts assessed costs and benefits in upholding the integrity of the federal structure against further extension of the Voting Rights Act, but other justices, looking at the same data, weighed the trade-offs differently (Charles and Fuentes-Rohwer 2015). Balance has in this way become another principle without traction. It exacerbates the very conditions the constitutional structure was designed to assuage-feeding, by turns, skepticism, volatility, and gridlock.

\section{A Constitution, in Principle}

It has been quite a while since principles sanctioned stable rules and an agreeable arrangement of authority. But, by itself, time elapsed is not dispositive. The administrative state was decades in the making, the resolution of 1946 following on reforms that stretched back to the 1880s. A more telling difference may be that, throughout those many decades of adjustment, a consistent line of response was discernible. A rising cadre of middle-class professionals was working all along on a new governing formula for industrial democracy, and they drew support for their administrative remedies from both of the major political parties. The reason for concern today is that the time since that last reset has not brought forth any new formula politically sturdy enough to build on nor any common carrier of new rules. On the contrary, alternatives are growing more discordant, and governing coalitions are drifting farther apart. The institutional system appears to be losing traction, seemingly unable to regain control of the competing claims pressing on it. Fifty years after the civil rights breakthrough jolted the administrative state, the shakedown of authority is still accelerating.

A long history of adjustment and successful adaptation steels the American psyche against this specter of a second-order threshold, a point beyond which the Constitution's response mechanisms cease to be effective in reducing stress and restoring a semblance of order. But developments are now bumping up against the assumption that old forms can be updated indefinitely, so long as we have the right principles. This article has elaborated on a simple historical-structural inference to raise doubts about that assumption and to call for closer scrutiny of adaptation as a developmental problem in its own right. The analysis suggests that the historic resilience of the Constitution may have been undermined by its greatest achievements, that the elimination of incongruous exclusions, and the associated openings to interests in contention, may have weakened categorically the adaptive capacities of its basic institutions.

Raising this possibility recasts the institutional problems of our day. If this diagnosis rings true, it will be harder to assert that the Constitution had it right at the start and that all we need do is find our way back to its true principles. It will also be harder to argue for plunging ahead on the view that modern governance is all about solving policy problems and that any necessary rearrangement of the furniture will take care of itself. This analysis resonates more closely with the concept of "constitutional rot" currently circulating among legal theorists (Balkin 2017; Jurecic and Wittes 2018). The idea there has been to distinguish current maladies from a constitutional "crisis" precipitated by some singular, sudden, or extraordinary event and to attend to other, more endogenous processes that might erode the system slowly from within. This article's call for closer attention to the mechanics of adaptation and their historical-structural implications is of a kindred spirit. Cognizant of past success in negotiating "crises," the adaptability paradox provides a roadmap to the very different challenges of governance now in view. 
Implicit in the adaptability paradox are a few developmental propositions that should be useful in refocusing the discussion going forward. They are offered here not as conclusions, but as a set of four postulates that shift the burden of plausibility onto proposed remedies:

1. Adjustments to the incorporation of new claimants relax constraints on government embedded in the formal structure of authority.

2. The burden on the government's principles increases with greater inclusion, eventually leaving authority wholly dependent on them.

3. When it's principles all the way down, each becomes harder to circumscribe, conflicts among them are exacerbated, and governing arrangements become more contestable.

4. Shorn of the categorical exclusions that once stiffened its forms and established firm boundaries on its principles, this government tends to flounder, unable to devise agreeable rules for institutional action and reset itself.

One response to these concerns might be just to let it rip. If it is true that rule-based regularity rested on exclusions, who needs it? This is an appealing sentiment, but it is not much of a solution. Even the most ardent democrat must recognize that rules are what make commitments credible and governments trustworthy. Developments that weaken them make it harder to secure the rights and sustain the programmatic supports that modern democracies demand. At the opposite extreme, one might be tempted to blame democracy and look for ways to roll back access and circumscribe commitments again. But if the goal is to stabilize affairs, this too seems a dubious strategy. It is one thing to assume ancient boundaries on inclusion and quite another to cut out people who have broken through them. Hard to defend as anything other than willful repression, after-the-fact restrictions are unlikely to alleviate the political pressures mounting on our basic institutions.

For those of sturdier faith, it will be tempting just to write off these concerns as a failure of imagination. It is not hard to think up ways that current problems of governance might be addressed through some further redeployment of the constitutional principles, and on the basis of what has been presented here, the possibility of another rabbit in the hat cannot be ruled out. One might, for example, imagine a new federalism that eases what now appear to be intractable and paralyzing conflicts at the center (Hais, Ross, and Winograd 2018). Decentralization might draw on more capable local governments and allow for a variety of different responses to the abortion debate, the education debate, the free exercise debate, and the like. But if the analysis offered here is correct, the recent course of development is not so easily discounted. How does a more inclusive, diverse, and demanding polity agree to such a radical devolution of power, with all that would imply for a re-imposition of local norms? Even if there are untapped efficiencies in service provision at the local level, how can they be disentangled from the disparate rights claims that now riddle social relations? Notwithstanding the resonance of this solution with the formal arrangements of the Constitution, any pronounced decentralization would seem to run afoul of the democratic achievements that eroded federalism's filters and boundaries in the first place.

Or consider the current scholarly articulation of alternatives to vacuous assertions of "balance." "Originalism" (on the right) and "proportionality" (on the left) respond directly to that concern (e.g., Jackson 2015; Matthews and Stone Sweet 2009; McGinnis and Rappaport 2013; Porat and Cohen-Eliya 2010). Each outlines principles that might reset the boundaries of rights and policy and reaffirm a meaningful distinction between the two. The principles employed, however, are very different, and they harbor devastating critiques of each other. The issue, as it has been posed here, is not theoretical; in principle, there are many possible solutions. The problem yet to be focused on is historical and structural: this polity is awash in its principles; through its own developmental processes, it seems to have eroded the ground for political agreement on any particular ordering of them.

Due regard for the adaptability paradox may make it harder to figure things out again, but there seems little hope for a solution that does not begin with that conundrum. Principles are abstract, demanding, and contentious. Government depends on arrangements that are resilient enough to manage their demands and legitimate enough to circumscribe their contention. If the platform of institutions and principles erected by the Constitution now appears hollow and wobbly, it may be because all the unprincipled material beneath it has finally been cleared away and because all the governing problems once dealt with down there by prior right have been piled atop the platform itself. That makes the emergent state - "the policy state" — a principled free-for-all, its actions and priorities no longer anchored by a robust sense of rights and a reliable structure of decision-making authority (Orren and Skowronek 2017). Far more inclusive than the party state of the nineteenth century or the administrative state of the twentieth century, this new formation is also unbridled in its instrumentalism, volatile in its politics, and unstable in its rules. The cumulative effects of development express themselves in America paradoxically, in democratic gains that have outstripped their institutional accommodations and put democracy itself at risk.

\section{Notes}

1 We use the term "prior right" rather than "common law" because of the disputed role of common law in the hierarchy of master and slave. 
2 McDonagh (2017) argues that the rights of parents over children remain hierarchical and insulated from the full reach of liberal principles. We observe that these arrangements too have become increasingly unsettled and have blossomed into major sticking points in national politics.

3 In Arnold's (1998, 431) depiction of the post-New Deal institutional settlement, "neutral competence was the conceptual nexus holding together administrative theory and democratic legitimacy."

4 The term "lawfare" is increasingly prominent in legal circles, as exemplified by the popularity of the blog Lawfare. Nevertheless, the connotation drawn out here is our own.

\section{References}

Abcarian, Robin. 2012. "College Transcripts Replace Birth Certificate for Obama Detractors." Los Angeles Times, May 28.

Aleinikoff, Alexander. 1987. "Constitutional Law in the Age of Balancing." Yale Law Journal 96(5): 943-1005.

Arnold, Jason Ross. 2014. Secrecy in the Sunshine Era: The Promises and Failures of U.S. Open Government Laws. Lawrence: University Press of Kansas, 2014.

Arnold, Peri. 1998. Making the Managerial Presidency: Comprehensive Reorganization Planning, 1905-1996. Lawrence: University Press of Kansas.

Balkin, Jack. 2017. "Constitutional Rot." In Can It Happen Here? Authoritarianism in America, ed. Cass Sunstein, 19-36. Public Law Research Paper 604. New Haven: Yale Law School.

Barnes, Robert. 2008. "The Political Wars Damage Public Perception of the Supreme Court." Washington Post, February 4.

Bateman, David. 2019. Disenfranchising Democracy: Constructing the Electorate in the United States. United Kingdom, and France. New York: Cambridge University Press.

Bateman, David, Ira Katznelson, and John Lapinski. 2018. Southern Nation: Congress and White Supremacy after Reconstruction. New York: Russell Sage.

Blake, Aaron. 2017. "Trump Is Not-So Subtly Threatening the Judicial System and Even His Supreme Court Nominee Is Upset." Washington Post, February 8.

Burnham, Walter Dean 1993. "Pattern Recognition and 'Doing' Political History." In The Dynamics of American Politics, eds. Larry Dodd and Calvin Jillson, 59-82. New York: Routledge.

Calabresi, Stephen and Christopher Yoo. 2008. The Unitary Theory of the Executive. New Haven: Yale University Press.

Caplan, Lincoln. 2015. "Justice Roberts's Court.” New Yorker, June 29.

Carney, Jordain. 2017. "GOP Eyeing 'Blue Slip’ Break to Help Trump Fill the Courts.” The Hill, September 17.
Charles, Guy-Uriel E. and Luis Fuentes-Rohwer. 2015. "Race Federalism and Voting Rights." University of Chicago Legal Forum 113-52.

Clinton, Hillary. 2016. "Acceptance Speech at the Democratic National Convention,” July 28. https://time.com/3920332/transcript-fu.

Concerned Members of the U.S. National Academy of Sciences. 2018. "Statement to Restore Science-Based Policy in Government," April. https://scientistsforsciencebasedpolicy.org.

Cook, Nancy and Andrew Restuccia. 2017. "Why the Trump Administration Has So Many Vacancies." Politico, April 11.

Corwin, Edward. 1950. "The Passing of Dual Federalism." Virginia Law Review 36: 1-36.

Croley, Steven. 2003. "White House Review of Agency Rulemaking: An Empirical Investigation." University of Chicago Law Review 70(3): 821-86.

Croly, Herbert. 1914. Progressive Democracy. New York: MacMillan. . [1909] 1965. The Promise of American Life. Cambridge, MA: Harvard University Press.

Dahl, Robert A. 1957. "Decision-Making in a Democracy: The Supreme Court as a National Policy-Maker." Journal of Public Law 6(2): 279-95.

Dewey, John. 1927. The Public and Its Problems. New York: Henry Holt.

Dinan, Stephen. 2018. "House Speaker Paul Ryan: 'Legitimate Questions about FBI's Behavior.” Washington Times, January 30.

Dionne, E. J. Jr., Norman J. Ornstein, and Thomas Mann. 2017. One Nation after Trump: A Guide for the Perplexed, the Desperate, and the Not Yet Deported. New York: St. Martins.

Donegan, Moira. 2017. "How Trump's Tax Returns Became a Liberal Fantasy." New Republic, April 18.

Edling, Max. 2003. A Revolution in Favor of Government: The U.S. Constitution and the Making of the American State. New York: Oxford University Press.

Emerson, Blake. 2017. “Administrative Answers to 'Major Questions': On the Democratic Legitimacy of Agency Statutory Interpretation." Minnesota Law Review 102(5): 2020-97.

Engel, Stephen. 2011. American Politicians Confront the Court. New York: Cambridge University Press.

Epstein, Richard. 2006. How the Progressives Rewrote the Constitution. Washington, DC: Cato Institute.

Eskridge, William N. Jr. and Lauren E. Baer. 2008. “The Continuum of Deference: Supreme Court Treatment of Agency Statutory Interpretations from Chevron to Hamdan." Yale Faculty Scholarship Series, Paper 3772. New Haven: Yale University.

Friedman, Lisa. 2018. "The E.P.A Says It Wants Research Transparency, Scientists See an Attack on Science." New York Times, March 26. 
Garcia v. San Antonio Metro. Transit Authority, 469 U.S. 528 (1985).

Gillman, Howard. 1997. "The Collapse of Constitutional Originalism and the Rise of the Notion of the 'Living Constitution' in the Course of American State Building." Studies in American Political Development 11: 191247.

Goldberg, Jonah. 2008. Liberal Fascism. New York: Doubleday.

Goldfarb, Ronald, ed. 2015. After Snowden: Privacy, Secrecy and Security in the Information Age. New York: St. Martins.

Gstalter, Morgan. 2018. "Trump Thanks Obama for Leaving So Many Judicial Vacancies." The Hill, March 29.

Hais, Mike, Doug Ross, and Morley Winograd. 2018. Healing American Democracy: Going Local. Tacoma, WA: Blue Zephyr.

Hamburger, Phillip. 1989. "The Constitution's Accommodation of Social Change." Michigan Law Review 88: 245-327.

2014. Is Administrative Law Unlawful? Chicago: University of Chicago Press.

Hill, Benjamin. [1876] 1893. "The Stars and Stripes." In Senator Benjamin Hill of Georgia: His Life, Speeches and Writings, 354-73. Atlanta: Bloodworth.

Hofstadter, Richard. 1949. "From Calhoun to the Dixiecrats." Social Research 82: 245-61.

1969. The Idea of a Party System: The Rise of Legitimate Opposition in the United States, 1780-1840. Berkeley: University of California Press.

Houk, Julie. 2015. "Rallying to Restore the Voting Rights Act." Voting Rights Project, July 7. Washington, DC: Lawyers' Committee for Civil Rights.

Hudson County Water Co. v. McCarter 209 U.S. 349 (1908).

Hult, Karen and Charles Walcott. 2004. Empowering the White House: Governance under Nixon, Ford and Carter. Lawrence: University Press of Kansas.

Jackson, Vicki. 2015. "Constitutional Law in an Age of Proportionality.” Yale Law Journal 124: 3094-3196.

Jurecic, Quita and Benjamin Wittes. 2018. "What Is a Constitutional Crisis, Really?" The Atlantic, March 17.

Katznelson, Ira, Kim Greider, and Daniel Kryder. 1993. "Limiting Liberalism: The Southern Veto in Congress, 1933-1950." Political Science Quarterly 108(2): 283306.

Kavanaugh, Brett. 2018. "Opening Statements.” Politico, September 4. https://www.politico.com/story/2018/ 09/04full text-brett-kavanaugh-confirmation-hearingopening-statements-806420.

Kersh, Kenneth. 2016. "Constitutional Conservatives Remember the Progressive Era." In The Progressives' Century: Political Reform, Constitutional Government and the American State, eds. Stephen Skowronek, Stephen Engel and Bruce Ackerman, 130-56. New Haven: Yale University Press.

Kinane, Christina. 2018. "Strategic Vacancies: The Presidential Advantage in Agency Appointments." Unpublished manuscript, University of Michigan.

Kincaid, John. 1990. "From Cooperative to Coercive Federalism." Annals of the American Academy of Political and Social Science 509: 139-52.

King, Desmond and Rogers Smith. 2005. "Racial Orders in American Political Development." American Political Science Review 99: 75-92.

Levinson, Sanford. 2012. America's 51 Constitutions and the Crisis of Governance. New York: Oxford University Press.

Lippmann, Walter. [1914] 1961. Drift and Mastery: An Attempt to Diagnose the Current Unrest. Englewood Cliffs, NJ: Prentice-Hall.

Liptak, Adam. 2018. "As Supreme Court Tips Right, Chef Justice Steers to Center." New York Times, December 24.

Madison, James. [1788] 1961. "Federalist 10." In The Federalist Papers, eds. Alexander Hamilton, James Madison, and John Jay, 76-84. New York: Mentor.

Matthews, Jud and Alec Stone Sweet. 2009. "Proportionality Balancing and Global Constitutionalism.” Journal of Transnational Law 72.

Mayer, Kenneth. 2001. With the Stroke of a Pen: Executive Orders and Presidential Power. Princeton, NJ: Princeton University Press.

McDonagh, Eileen. 2017. "The Feudal Family: A Road Block to American Political Development." Paper presented at the annual meeting of the American Political Science Association.

McGarity, Thomas and Wendy Wagner. 2008. Bending Science: How Special Interests Corrupt Public Health Research. Cambridge, MA: Harvard University Press.

McGinnis, John and Michael Rappaport. 2013. Originalism and the Good Constitution. Cambridge, MA: Harvard University Press.

McNollgast. 1999. "The Political Origins of the Administrative Procedure Act." Journal of Law Economics and Organization 15: 180-217.

Michaels, Jon. 2017. Constitutional Coup: Privatization's Threat to the American Republic. Cambridge, MA: Harvard University Press.

Moe, Terry. 1985. "The Politicized Presidency." In The New Direction in American Politics, eds. John Chubb and Paul Peterson, 235-73. Washington, DC: Brookings Institution.

Nathan, Richard. 1983. The Administrative Presidency. New York: Wiley.

Nelson, Michael. 2018. Trump's First Year. Charlottesville: University of Virginia Press.

Orren, Karen. 1992. Belated Feudalism: Labor, the Law, and Liberal Development in the United States. New York: Cambridge University Press. 
Orren, Karen and Stephen Skowronek. 2004. The Search for American Political Development. New York: Cambridge University Press. . 2017. The Policy State: An American Predicament. Cambridge, MA: Harvard University Press.

Plessy v. Ferguson 163 U.S. 537 (1896).

Porat, Iddo and Moshe Cohen-Eliya. 2010. "American Balancing and German Proportionality: The Historical Origins." International Journal of Constitutional Law 8(2): 263-86.

Rappeport, Alan. 2017. "C.B.O Head, Who Prizes Nonpartisanship Finds Work under G.O.P Attack." New York Times, June 19.

Regents of the Univ. of Cal. v. Bakke 438 U.S. 265 (1978).

Reeve, Elspeth. 2011. "White House Releases Obama's Original Birth Certificate." The Atlantic, April 27.

Reich, Robert. 2017. "The Crisis of Governance." https:// robertreich.org/post/158699399915.

Restuccia, Andrew, Marianne Levine, and Nahal Toosi. 2017. "Federal Workers Turn to Encryption to Thwart Trump.” Politico, February 2.

Roberts, John. 2005. "Confirmation Hearing on the Nomination of John G. Roberts.” CNN, September 12. http://www.cnn.com/2005/POLITICS/09/12/roberts.statement/.

Rosen, Jeffrey. 2007. "Roberts's Rules." The Atlantic, January/February.

Sasse, Stephanie Fine and Lucky Tran, eds. 2017. Science Not Silence: Voices from the March for Science Movement. Cambridge, MA: MIT Press.

Schudson, Michael. 2015. The Rise of the Right to Know: Politics and the Culture of Transparency, 1945-1975. Cambridge, MA: Harvard University Press.

Shelby County v. Holder 570 U.S. 2 (2013).

Shepherd, George. 1996. "Fierce Compromise: The Administrative Procedure Act Emerges from the New Deal."Northwestern University Law Review 90: 1557-1683.

Silbey, Joel. 1983. “'There Are Other Questions beside that of Slavery Merely': The Democratic Party and Antislavery Politics." In Crusaders and Compromisers: Essays on the Relationship of the Antislavery Struggle to the Antebellum Party System, ed. Alan M. Kraut, 143-75. Westport, CT: Greenwood.
1985. The Partisan Imperative: The Dynamics of American Politics before the Civil War. New York: Oxford University Press.

Skowronek, Stephen. 1982. Building a New American State: The Expansion of National Administrative Capacities, 1877-1920. New York: Cambridge University Press.

. 2006. "On the Interpenetration of Antithetical Ends: Liberalism and Racism in the American Political Tradition." American Political Science Review 100: 385401.

Skrentny, John. 2004. The Minority Rights Revolution. Cambridge, MA: Harvard University Press.

Smith, Rogers. 1997. Civic Ideals. New Haven: Yale University Press.

Sollenberger, Mitchell and Mark Rozell. 2012. The President's Policy Czars: Undermining Congress and the Constitution. Lawrence: University Press of Kansas.

Strong, Frank. 1938. “Cooperative Federalism.” Iowa Law Review 23: 459-518.

Sundquist, James. 1981. The Decline and Resurgence of Congress. Washington, DC: Brookings Institution.

Truman, David. 1951. The Governmental Process: Political Interests and Public Opinion. New York: Knopf.

Urbina, Francisco. 2017. A Critique of Proportionality and Balancing. New York: Cambridge University Press.

Waddell, Melanie. 2018. “'Big, Beautiful Scissors' Are Cutting Regs: Trump's Regulatory Czar." National Law Journal, January 26.

Walker, Anders. 2010. "Diversity's Strange Career: Recovering the Racial Pluralism of Lewis F. Powell." Santa Clara Law Review 50: 647-80.

Weingast, Barry. 1998. "Political Stability and Civil War, Institutions, Commitments and American Democracy." In Analytic Narratives, eds. Robert H. Bates, Avner Greif, Margaret Levi, Jean-Laurent Rosenthal, and Barry R. Weingast, 148-93. Princeton, NJ: Princeton University Press.

White, Morton. 1947. Social Thought in America: The Revolt against Formalism. Boston: Beacon.

Wiebe, Robert. 1995. Self-Rule. Chicago: University of Chicago Press. 